\title{
Asset Acquisition or Business Combination? Application of Definition of a Business in Real Estate Industry
}

\author{
Zhe Ruan \\ China Merchants Group Limited, Hong Kong, China \\ Email: mlbsabc@sina.com
}

How to cite this paper: Ruan, Z. (2021). Asset Acquisition or Business Combination? Application of Definition of a Business in Real Estate Industry. Open Journal of Accounting, 10, 9-16.

https://doi.org/10.4236/ojacct.2021.101002

Received: October 21, 2020

Accepted: January 9, 2021

Published: January 12, 2021

Copyright $\odot 2021$ by author(s) and Scientific Research Publishing Inc. This work is licensed under the Creative Commons Attribution International License (CC BY 4.0).

http://creativecommons.org/licenses/by/4.0/

\section{(c) (i) Open Access}

\begin{abstract}
The International Accounting Standards Board issued Definition of a Business (Amendments to IFRS 3) on 22 October 2018. The amendments clarify the definition of a business, with the aim of helping entities to determine whether a transaction should be accounted for as an asset acquisition or a business combination. However, it remains ambiguous whether an acquired contract for outsourced property management, which is common in real estate industry, constitutes a substantive process. We adopt a comprehensive test approach to make the assessment and conclude the approach is more objective and easy to implement. Apart from it, we also recommend further clarification and guidance of standards in this regard.
\end{abstract}

Keywords

Business Combination, Asset Acquisition, IFRS 3, Real Estate Industry

\section{Introduction of IFRS 3 and Relevant Applications in Accounting Standards}

\subsection{Requirements of IFRS 3}

IFRS 3 Business Combinations outlines the accounting when an acquirer obtains control of a business (e.g. an acquisition or merger). Such business combinations are accounted for using the "acquisition method", which generally requires assets acquired and liabilities assumed to be measured at their fair values at the acquisition date. IFRS 3 para 2(b) explicitly excludes the acquisition of an asset or a group of assets that does not constitute a business. So the accounting treatments for a business combination and an asset acquisition differ significantly relating to deferred tax, contingent consideration, acquisition-related costs, and 
gains on bargain purchases.

PricewaterhouseCoopers (2017) discusses the main differences. Under asset acquisition, the acquirer shall allocate the purchase price to the individual identifiable assets and liabilities on the basis of their relative fair values and it does not give rise to goodwill. No deferred tax is recognized under IAS 12, given the initial recognition exception stated in IAS 12 para 15(b). Contingent liabilities are not recognized either, although the presence of contingent liabilities might impact transaction price and asset valuation. Besides, transaction costs form part of the cost of the asset.

While under business combination, the acquirer shall recognize and measure the identifiable assets and liabilities at their acquisition-date fair values and recognize any related goodwill or negative goodwill. Deferred tax is recognized in accordance with IAS 12. Contingent liabilities that are a present obligation arising from past events and can be reliably measured should be recognized at fair value. This is the case even if it is not probable that a future outflow of economic benefits will occur. Besides, transaction costs are expensed in the period incurred.

Summary of accounting differences between an asset acquisition and a business combination is presented in Table 1.

Given the accounting differences, it is crucial to interpret and apply the definition of a business. However, before 2018 Amendments, the standards adopt the perspective of market participants. Some sets of activities and assets might

Table 1. Accounting differences between an asset acquisition and a business combination.

\begin{tabular}{|c|c|c|}
\hline & Asset acquisition & Business combination \\
\hline Assets and liabilities & $\begin{array}{l}\text { Allocate the purchase price to the } \\
\text { individual identifiable assets and } \\
\text { liabilities on the basis of their relative } \\
\text { fair values }\end{array}$ & $\begin{array}{l}\text { Recognize and measure the iden- } \\
\text { tifiable assets and liabilities at } \\
\text { their acquisition-date fair values }\end{array}$ \\
\hline Goodwill & Not recognized & $\begin{array}{l}\text { recognize any related goodwill or } \\
\text { negative goodwill }\end{array}$ \\
\hline Deferred tax & $\begin{array}{l}\text { No deferred tax is recognized under } \\
\text { IAS } 12 \text {, given the initial recognition } \\
\text { exception }\end{array}$ & $\begin{array}{l}\text { Deferred tax is recognized in } \\
\text { accordance with IAS } 12\end{array}$ \\
\hline Contingent liabilities & Not recognized & $\begin{array}{l}\text { Contingent liabilities that are a } \\
\text { present obligation arising from } \\
\text { past events and can be reliably } \\
\text { measured should be recognized } \\
\text { at fair value }\end{array}$ \\
\hline Transaction costs & Form part of the cost of the asset & Expensed in the period incurred \\
\hline $\begin{array}{l}\text { Subsequent measurement } \\
\text { implications }\end{array}$ & Follow relevant standards for each asset & $\begin{array}{l}\text { Follow relevant standards for } \\
\text { each asset; annual impairment } \\
\text { test for any recognized goodwill } \\
\text { is required }\end{array}$ \\
\hline
\end{tabular}

Source: PricewaterhouseCoopers (2017) Applying IFRS for the real estate industry. 
have been considered a business from the perspective of particular market participants who could integrate the set in their processes. However, the same sets of activities and assets might not have been considered a business from the perspective of other market participants. So the definition of a business was broad and IFRS 3 had no guidance identifying when an acquired set of activities and assets is not a business.

The 2018 Amendments clarify the minimum attributes that the acquired set of activities and assets must have to be considered a business, remove the assessment of whether market participants are able to replace missing inputs or processes and continue to produce outputs, and add an optional concentration test that allows a simplified assessment of whether an acquired set of assets is not a business.

Grant Thornton (2019) introduces 5-step tests to determine if the acquired set of activities and assets is a business. The first three steps require the entity to consider whether to apply the concentration test. If yes, the entity will consider what assets have been acquired and how the fair value of gross assets acquired is concentrated. If the concentration test has passed, transaction is not a business. If no, the entity will consider whether the acquired set of activities and assets has outputs and whether the acquired process is substantive.

The 5-step tests are presented in Table 2.

\subsection{Illustrative Examples Analysis}

9 examples, namely example A-I, in Amendments to the Illustrative Examples accompanying IFRS 3 (2019) illustrate application of the guidance in para B7-B12D on the definition of a business. Example A-acquisition of real estate, explicitly relates to applications in real estate industry. It concludes that processes performed by the outsourced cleaning, security and maintenance personnel are ancillary or minor within the context of all the processes required to

Table 2. 5-step tests introduced by Grant Thornton.

\begin{tabular}{cll}
\hline Steps & \multicolumn{1}{c}{ Tests } & \multicolumn{1}{c}{ Questions } \\
\hline Step 1 & $\begin{array}{l}\text { Consider whether to apply the concentration } \\
\text { test }\end{array}$ & $\begin{array}{l}\text { Does the entity want to apply the } \\
\text { concentration test? }\end{array}$ \\
Step 2 Consider what assets have been acquired & $\begin{array}{l}\text { Has a single identifiable asset or a group } \\
\text { of similar identifiable assets been } \\
\text { acquired? }\end{array}$ \\
Step 3 & $\begin{array}{l}\text { Consider how the fair value of gross assets } \\
\text { acquired is concentrated }\end{array}$ & $\begin{array}{l}\text { Is substantially all of the fair value of the } \\
\text { gross assets acquired concentrated in a } \\
\text { single identifiable asset or a group of } \\
\text { similar identifiable assets? }\end{array}$ \\
& $\begin{array}{l}\text { Consider whether the acquired set of activities } \\
\text { and assets has outputs }\end{array}$ & $\begin{array}{l}\text { Does the acquired set of activities and } \\
\text { assets have outputs? }\end{array}$ \\
Step 5 & Consider if the acquired process is substantive & $\begin{array}{l}\text { When the acquired process is considered } \\
\text { substantive? }\end{array}$
\end{tabular}

Source: Grant Thornton (2019) Insights into IFRS 3. 
create outputs. So if the outsourced cleaning, security and maintenance personnel are the only processes acquired, the acquired set of activities and assets is not a business.

On the other side, if acquired set of activities and assets also includes the employees responsible for leasing, tenant management, and managing and supervising all operational processes, processes are substantive because leasing, tenant management, and managing and supervising the operational processes are critical to the ability to continue producing outputs when applied to the acquired inputs (i.e. the land, buildings and in-place leases). So Purchaser concludes that the acquired set of activities and assets is a business.

\section{Comprehensive Test Approach in Real Estate Industry}

\subsection{Special Features of REITs}

REITs, or real estate investment trusts, are companies that own or finance income-producing real estate across a range of property sectors. The recent low interest rate environment helps them produce attractive return to REITs investors. The two main types of REITs are equity REITs and mortgage REITs (PricewaterhouseCoopers, 2019). Equity REITs generate income through the collection of rent on, and from sales of, the properties they own for the long-term. Mortgage REITs invest in mortgages or mortgage securities tied to commercial and/or residential properties. Equity REITs usually purchase property with in-place leases from property developers. The in-place leases indicate that the set of activities and assets has outputs. In real estate industry, leasing, tenant management, and managing and supervising the operational processes are critical to the ability to continue producing outputs (as mentioned in Section 2.2). But they are seldom considered unique or scarce and can be replaced without significant cost, effort, or delay in the ability to continue producing outputs, as there exist considerable property management teams in the market. The legal structure of REITs in some jurisdictions, including Hong Kong, prohibits the transfer of employees who are responsible for leasing, tenant management, and managing and supervising the operational processes from property developers to REITs. So a contract for outsourced property management or outsourced asset management is enacted between parties to manage the property and generate rental income. Ambiguity arises whether an acquired contract may give access to an organized workforce or not.

\subsection{Comprehensive Test}

Special attention should be paid to the outsourced contract. Factors to be considered in making that assessment include the duration of the contract and its renewal terms. If the outsourced property management contract does not have business substance, or differs significantly compared with common business practice, or likely expires in a short period of time, then REITs do not faithfully acquire an organized workforce through an outsourced contract. 
We, therefore, propose a comprehensive test approach to address to definition of business problem in real estate industry. The first step is to consider whether to apply the concentration test. If yes, then the entity will consider if substantially all of the fair value of the gross assets acquired is concentrated in a single identifiable asset or a group of similar identifiable assets in step two. If the answer to step two is yes, then it is concluded that the acquired set of activities and assets is not a business. If no, then step three should be looked at. Although IFRS 32018 amendments make concentration test optional as it enables entities to assess whether they have acquired a substantive process when such an assessment would be more efficient than applying the concentration test, or would result in a conclusion that more faithfully represents the economics of a particular transaction, concentration test in real estate industry is more objective because the fair value of the gross assets acquired is usually concentrated in land or investment property. Only when acquired assets are not similar identifiable assets shall we access whether an acquired process is substantive.

Step three requires entity to identify processes that are critical to the ability to continue producing outputs. In real estate industry, leasing, tenant management, and managing and supervising the operational processes should be considered as critical processes. In the next two steps, the entity shall assess whether the inputs acquired directly or indirectly (which means through an outsourced contract) include an organized workforce. If either answer is yes, then the acquired set of activities and assets is a business. Otherwise, it is not a business.

Summary of the comprehensive test is presented in Figure 1.

\subsection{Benefits of Comprehensive Test}

The comprehensive test effectively addresses the definition of business problem in real estate industry. Firstly, it relies heavily on concentration test as it is more objective and easy to implement. The concentration test achieves the same outcome as the detailed assessment otherwise required by para B8-B12D in IFRS 3 for transactions between REITs and property developers. Secondly, it identifies leasing, tenant management, and managing and supervising the operational processes are the processes critical to the ability to continue producing rental income. The conclusion generally holds true and saves time in further assessment. Thirdly, it points out an organized workforce can be acquired directly or indirectly through an outsourced contract. So the structure of transactions should be carefully designed to achieve the expected business goals.

\subsection{Cases Study of Application of Comprehensive Test}

Assume acquired assets are not similar identifiable assets (for example, the single-family homes and the office park) as the scale of operations and risks associated with the assets are significantly different, so we cannot apply the concentration test in the first two steps in the abovementioned comprehensive test. We will discuss how different structure of transactions affects the assessment of business using our comprehensive test. 


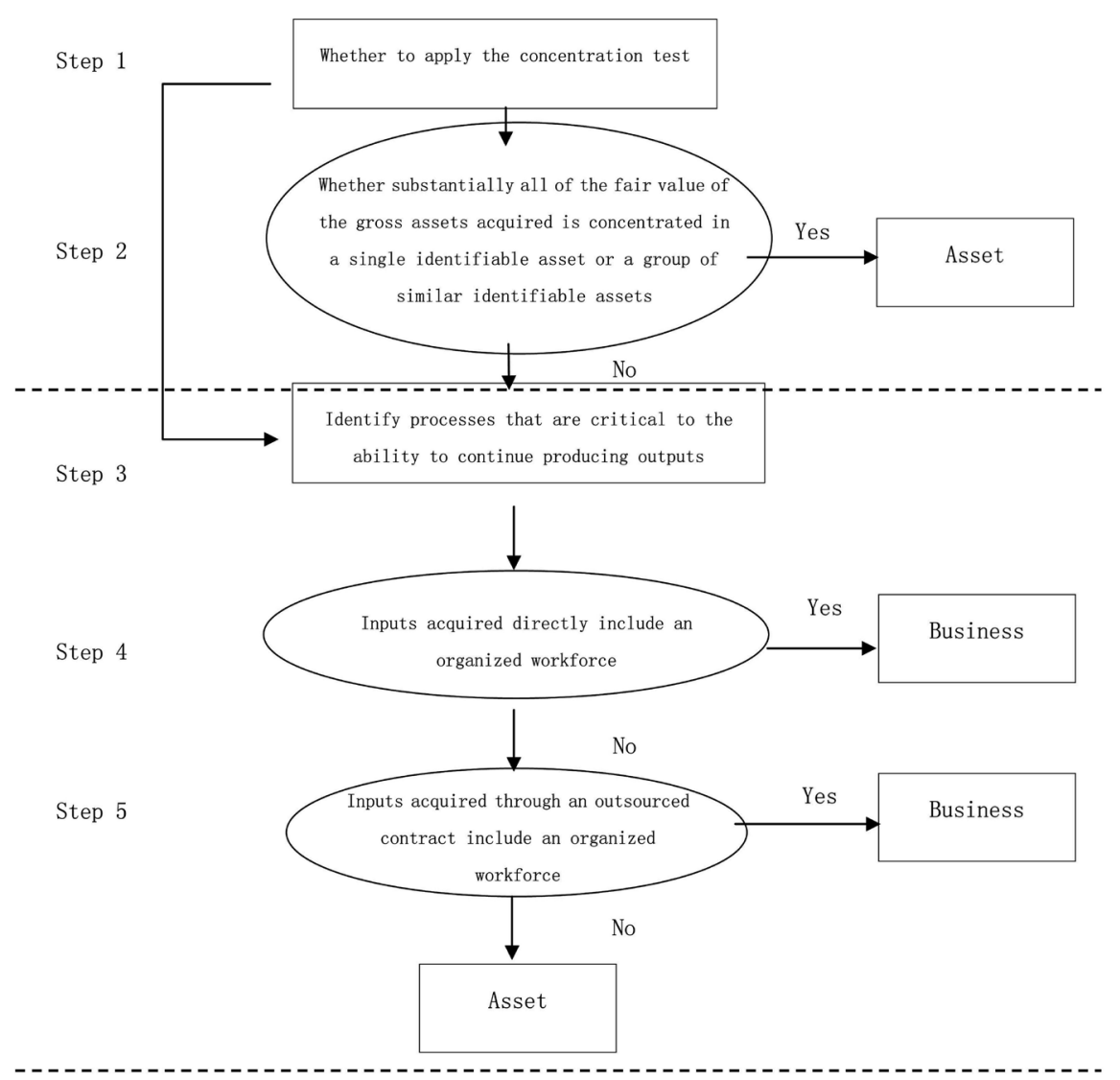

Figure 1. Comprehensive test.

In one extreme, if the purchaser does not acquire an organized workforce and will take over processes that are critical to the ability to continue producing outputs, clearly inputs acquired do not include an organized workforce and the acquired set of activities and assets is not a business. It is the case when CK Hutchison Holdings Limited (2013) sold Fortune Mall to Fortune REIT in 2013 and Fortune REIT took over the property management role. CK Hutchison Holdings Limited (2013) recognized assets disposal gains of HKD 2760 million in its annual report.

If the purchaser and seller form a general partnership to manage the property and the partnership is controlled by the purchaser or under common control, we conclude inputs acquired do not include an organized workforce and the acquired set of activities and assets is not a business as the seller contributes insignificant portion of workforce with the necessary skills, knowledge, or experience to perform that process. It is the case when FRASERS Commercial Trust (2017) formed a joint venture in 2017 with Frasers Centrepoint Limited to acquire $£ 175$ million Farnborough Business Park in the United Kingdom.

If the purchaser and seller signs an outsourced property management contract that allows the seller to remain its property management role and the contract has finite duration, or seller can be easily replaced with other property management companies in the market, it is probable that inputs acquired do not include 
an organized workforce and the acquired set of activities and assets is not a business. It is the case when YUEXIU Property (2017) sold Wuhan Property to YUEXIU REIT in 2017 and buyer and seller entered into property management contract that lasts for four years. YUEXIU Property (2017) recognized gain on disposal of a subsidiary of RMB 442 million in its annual report.

If the purchaser and seller signs an outsourced property management contract and it is unlikely that seller will be replaced (for example, the replacement needs majority consent from REITs holders while seller holds significant portion of REITs and other shareholdings of REITs is highly decentralized), it is likely that inputs acquired include an organized workforce and the acquired set of activities and assets is a business. It is the case when China Merchants Shekou Industrial Zone Holdings Co., Ltd. (2019) sold 5 properties in Shenzhen to China Merchants Commercial REIT in 2019. China Merchants Shekou Industrial Zone Holdings Co., Ltd. (2019) holds 33.5\% of China Merchants Commercial REIT and the rest shareholdings of REITs are highly decentralized. The outsourced property management contract becomes invalid only when majority shareholders vote against it. So China Merchants Shekou Industrial Zone Holdings Co., Ltd. (2019) recognized gain on disposal of subsidiaries of RMB 4286 million.

In the other extreme, if the purchaser and seller signs an outsourced property management contract that has infinite duration and the seller cannot be replaced, an organized workforce is likely to be transferred although we need be cautious whether the purchaser has power over the investee (i.e. REITs) according to IFRS 10. We will further elaborate in Section 4.

Summary of different scenarios is listed in Table 3.

\section{Recommendations on Further Standards Clarification and Guidance}

It becomes an interesting story in the final scenario when property developer sells the property to REITs while remain the property management role either

Table 3. Discussion of different scenarios of REITs transaction structure.

\begin{tabular}{llcc}
\hline \multicolumn{1}{c}{ Scenario } & $\begin{array}{c}\text { Inputs acquired include } \\
\text { an organized workforce? }\end{array}$ & Asset or business? \\
\hline Scenario 1 & $\begin{array}{l}\text { Purchaser take over property management } \\
\text { Purchaser and seller form a general partnership to manage the }\end{array}$ & No & Asset \\
Scenario 2 & $\begin{array}{l}\text { property and the partnership is controlled by the purchaser or } \\
\text { under common control }\end{array}$ & No & Asset \\
& $\begin{array}{l}\text { Purchaser and seller signs an outsourced property } \\
\text { management contract and the contract has finite during, or } \\
\text { seller can be easily replaced }\end{array}$ & Yes & Asset \\
Scenario & $\begin{array}{l}\text { Purchaser and seller signs an outsourced property management } \\
\text { contract and it is unlikely that seller will be replaced }\end{array}$ & Yes & $\begin{array}{l}\text { Business (consider whether the purchaser } \\
\text { has power over the investee) }\end{array}$ \\
\hline Scenario 5 & Seller remain the property management role & &
\end{tabular}


through outsourced contract with infinite duration or through special arrangement that seller cannot be replaced. The purchaser is believed to acquire inputs including an organized workforce with the necessary skills, knowledge, or experience to perform the tasks. However, the purchaser lacks rights that give the current ability to direct the activities that significantly affect the investee's returns because they are not allowed to manage the property or replace the property management team. So it is highly doubtful whether the REIT has control over the property. This structure of transaction gives rise to the conflicts between IFRS 3 and IFRS 10. Further study and comprehensive review of IFRS 3 and IFRS 10 is suggested.

\section{Conclusion and Deficiency}

We address the problem of whether a sale of investment property from property developers to REITs should be accounted for as an asset acquisition or a business combination under Definition of a Business (Amendments to IFRS 3) by introducing a 5-step comprehensive test. We also summarize the common transaction structures that took place in the market and assess them using our test. The results are consistent and objective. However, we are not able to analyze every single transaction structure and similar transaction structure with one critical amendment could make the assessment result totally different.

\section{Conflicts of Interest}

The authors declare no conflicts of interest regarding the publication of this paper.

\section{References}

China Merchants Shekou Industrial Zone Holdings Co., Ltd. (2019). 2019 Annual Report. https://www.cmsk1979.com/investor.aspx?type $=32$

CK Hutchison Holdings Limited (2013). 2013 Annual Report. https://doc.irasia.com/listco/hk/ckh/annual/2013/car2013.pdf

FRASERS Commercial Trust (2017). Joint venture with Frasers Centrepoint Limited to Acquire $£ 175$ Million Farnborough Business Park in the United Kingdom. https://fcot.frasersproperty.com/newsroom/20171214 182225 ND8U L74PJ059COT WV05M.2.pdf

Grant Thornton (2019). Insights into IFRS 3. https://www.grantthornton.ie/insights/publications/insights-into-ifrs-3-definition-of-a -business/

PricewaterhouseCoopers (2017). Applying IFRS for the Real Estate Industry. https://www.pwc.com/gx/en/audit-services/ifrs/publications/applying-ifrs-for-the-realestate-industry.pdf

PricewaterhouseCoopers (2019). Worldwide Real Estate Investment Trust (REIT) Regimes.

https://www.pwc.com/gx/en/asset-management/assets/pdf/worldwide-reit-regimes-no v-2019.pdf

YUEXIU Property (2017). 2017 Annual Report. https://doc.irasia.com/listco/hk/yuexiuproperty/annual/2017/ar2017.pdf 